\title{
Research article: Production and marketing pattern of banana in Nagaon district of Assam
}

\author{
Trishnalee Saikia, K.C. Bora and Horindra Gogoi
}

Article Chronicle : Received :

28.02.2018;

Revised :

02.04.2018;

Accepted :

15.04.2018

KEY Words:

Market intermediaries,

Pre-harvest

contractors, Distant

wholesaler, Marketing

cost, Marketing

margin, Marketing

efficiency
Author for correspondence:

Trishnalee Saikia

Krishi Vigyan Kendra

(AAU), Sivasagar

(Assam) India

Email:trishnaleesaikia@ gmail.com

See end of the article for authors' affiliations
SUMMARY : The study was conducted to examine the marketing pattern of banana in Nagaon district of Assam. The marketing process of banana in the study area was facilitated by various market intermediaries like pre harvest Contractors cum Processor (Distant), Pre harvest Contractors cum wholesaler, Distant Wholesaler, Local traders etc. The pre-harvest contractors play a vital role in marketing of banana in the district. Out of the six marketing channels identified in the study area, major portion of produces were sold through channel II (Producer-Pre harvest Contractors cum wholesaler Distant Wholesaler -Distant Retailers - Consumers) where the pre-harvest contractors cum wholesalers directly brought the produces to distant markets and sold to distant wholesalers and thereby to distant retailers and then to consumers. Within the district major marketing channel was observed to be channel IV (Producer- Wholesalers-retailers -consumers) where 26.53 per cent of the total produce by the sample farms were routed to the ultimate consumers through the wholesalers and retailers. Channel V (Producer-Retailers - Consumers) was found to be the most efficient channel in marketing of banana in Nagaon district with the efficiency index of 1.764 (following the Shepherds' approach) involving middlemen.

How to cite this article : Saikia, Trishnalee, Bora, K.C. and Gogoi, Horindra (2018). Production and marketing pattern of banana in Nagaon district of Assam. Agric. Update, 13(2): 197-202; DOI : 10.15740/HAS/AU/13.2/ 197-202. Copyright@2018: Hind Agri-Horticultural Society. 